\title{
フルイディック発振器内の流れの可視化
}

的場 識義 (同志社大学), 平田 勝哉 (同志社大学), 舟木 治郎 (同志社大学)

\section{Flow Visualization in A Fluidic Oscillator}

\author{
Noriyoshi MATOBA, Katsuya Hirata and Jiro Funaki
}

\begin{abstract}
A confined jet sometimes causes self-exited oscillations due to an existence of a downstream obstacle. This phenomenon is useful for fluidic oscillators, heat/material mixers and flowmeters, in order to realize a low-cost high-reliability device without mechanically moving components. In the present paper, the authors study this phenomenon at low Reynolds numbers ( $R e \leqq 1000$ ), experimentally. More specifically, the authors deal with a two-dimensional confined jet into an abruptly expanding channel with a downstream square-cylinder target. As a result, the authors measured the flow patterns by PIV (Particle Image Verocimatry), and are classified into three types. Moreover, as a result of flow visualization by the digital camera, authors revealed that depends for oscillation frequency on the flow of the downstream of a square cylinder.
\end{abstract}

Keywords: Fluidic Oscillator, Flowmeter, Fluid Logic, Flow Induced Vibration, Flip-Flop Jet

\section{1. 緒言}

拘束噴流は，しばしば，下流の障害物により自励発振す る.この現象は, フルイディック発振器や，熱および物 質混合器, 流量計などへの応用が有望である.なぜなら， 機械的可動部がない為，安価で高信頼度の装置を実現す ることができるからである. 流量計一の応用を意図して， Yamasaki, Takahashi\&Honda(1988)1)は, 最も単純な幾 何形状の 1 つ，すなわち，下流に正方形柱を設直した 2 次元急拡大管を調べた. 流体自励発振現象を利用した流 量計には, カルマン渦列型流量計や, 渦歳差型流量計, 噴流発振型流量計などがあり，以下のような共通の長所 を持つ. (1)機械的可動部を持たないことによる高い信頼 性. (2)発振周波数と流量の線形性. (3)流体の密度や温度, 圧力, 組成の影響を受けにくい，噴流発振型流量計はし ばしば,フルイディック型流量計あるいはフルイディッ ク振動子型流量計と呼ばれる.ここに, “フルイディック” の語源は, 流体論理素子(フルードロジック)あるいはフル イディクスにあり，その研究は 1960 年代に大きく発展 した. (例えば, 文献 $\left.{ }^{2}\right)$ しかしながら，多くのフルイディ ック発振器は, コントロールポート，フィードバックル 一プなどにより，構造が複雑である。(例えば，文献 $\left.{ }^{3)}\right)$ 少数の例外は以上に述べたものと, Shakouchi(1989)4) によって提案された三次元構造を持っものである.最近, マイクロマシンの高まる必要性が, 他の装置と同様に発振器
についても小型化を促している.この研究において, 著者ら

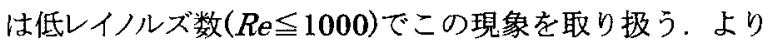
具体的には，著者らは，下流に正方形柱を設置した急搪 大管に流れ込む二次元拘束噴流を実験的に扱う.

これまでの研究において，著者らは，レイノルズ数お よび発振器の形状パラメータが発振周波数と発振領域に あたえる影響を調查し，低レイノルズ数領域 $(R e-$ 100-1000)で流量計として適した形状パラメータが存在 することを示した ${ }^{5)}$.

今回の実験では，著者らは，1 周期間のフルイディッ ク発振器内の連続フローパターンを PIV(Particle Image Velocimetry)によって測定し, 噴流発振中の発振器内部 流れの変遷を明らかにする．また，デジタルカメラを用 いて発振器内の流孔を可視化し，噴流の発振周波数に関 倸する流れを特定することを試みる.

\section{2.おもな記号および単位}

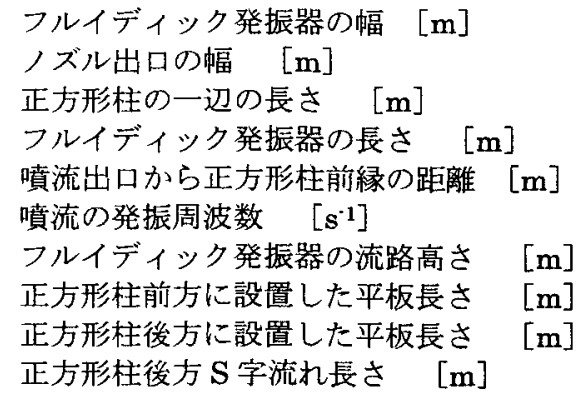




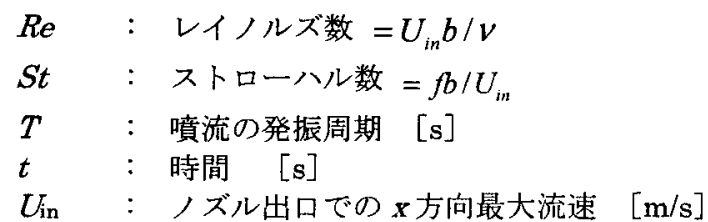

\section{3. 実験方法}

\section{1 実験装膡}

Fig. 1 に,この研究に使用した実験装置を示す. 水は, ポンプ(8によりメインタンク (1)へ汲み上げられ，発振器 (4)に流れ込む. 圧力差は，メインタンク(1)取り付けら れたオーバーフローによって常に一定に保たれる，てし て，流量は圧力差を一定にしておくことで一定に保つこ とができる、流量はバルブ(2)によって調整する。 ノズル 出口(幅 $b=1.2 \times 10^{-2} \mathrm{~m}$, 高さ $h=1.2 \times 10^{-1} \mathrm{~m}$ )から発振器(長 さ $\left.D=6.0 \times 10^{-1} \mathrm{~m}\right)$ 一流れ込む噴流は，ノズル出口の下 流に置かれた正方形柱(5)の存在により発振を起こす。 (Fig. 2 にこの研究のために使用されたフルイディック 発振器の詳細を示す） そして，水はサブタンク(7)に溜 められ，ポンプ(8によりメインタンク(1)人と再び汲み上 げられ，水は循環する。

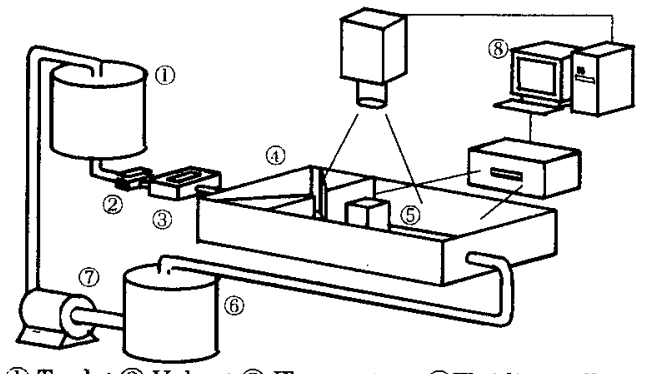

(1) Tank ; (2) Valve ; (3) Flow meter ; (4)Fluidic oscillator ; (5)Square cylinder ; (6)Sub- tank ; (7) Pump : (8PIV system Fig. 1 Experimental apparatus.

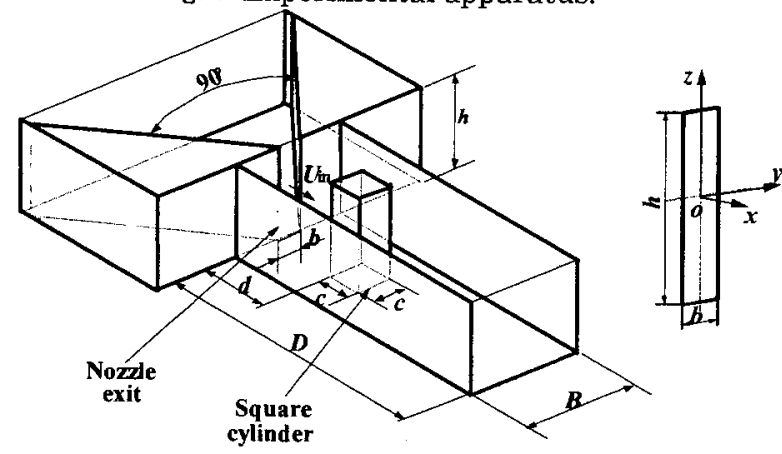

Fig. 2 Fluidic oscillator.

\section{2 可視化実験(可視化写真および PIV)}

フルイディック発振器内のフローパターンを撮影し, 相互相関法による PIV(Particle Image Velocimetry)によ つて解析する. YAG レーザーをフルイディック発振器の 側面から照射する.そして, $\mathrm{x} \cdot \mathrm{y}$ 平面内の流れをフルイデ イック発振器上部に設置した CCD カメラにより撮影す
る. (Fig. 1 を参照)また, 可視化写真も同様に発振器側面 から YAGレーザーを照射し,フルイディック発振器上部 に設固したデジタルカメラにより撮影する、なお, PIV, 可視化写真ともに，トレーサー粒子として，比重の調整 やレーザーに対する反射を強めるため, 蛍光塗料を表面 にコーティングしたポリスチレン粒子を用いた，平均粒 子径は $5.5 \times 10^{\circ 5}[\mathrm{~m}]$ である。

\section{4. 実験結果および考察}

4.1 流れの可視化

4.1.1一周期間のフローパターン

一周期閒の発振器内のフローパターンをPIVによって 可視化した.Fig. 3 は 1/8 周期ごとの連続したフローパタ ーンを示す.Fig. 4 はFig. 3 に対応する渦度分布図であ

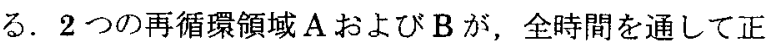
方形柱の上流で観察できる. $t=778$ では，2つの大規模渦 構造 C および D は正方形柱の下流で観察できる．また， 噴流が上方一偏向している. 正方形柱下流で Cから D 方 向八の流れが, 若干優勢である. $t=278$ では, 渦構造 $\mathrm{C}$ が下流に流される、正方形柱下流で D から $\mathrm{C}$ 一の流れが 優勢となる， $t=3778$ で噴流は，下方八偏向する， $t=4778$ で，渦構造 C および D は下流に流され， $t=5 \pi 8$ では， 新たな渦構造 $\mathrm{E}$ が正方形柱の下流に再び観察できる. $t=678$ で, 最初から存在していた渦構造 D は下流に流さ れる. $t=8778$ で，新たな渦構造 $\mathrm{F}$ が再び観察できる。

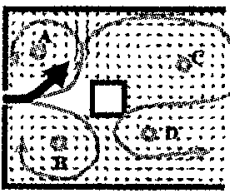

(a) $t /=T / 8$

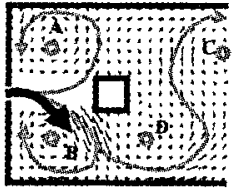

(c) $t=3 T / 8$

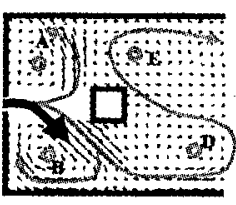

(e) $t=5 T / 8$

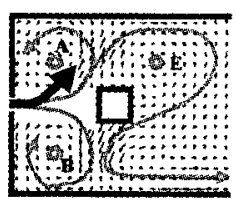

(g) $t=7 T / 8$

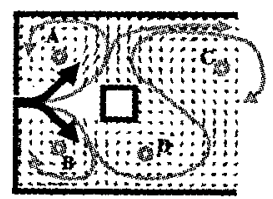

(b) $t=27 / 8$

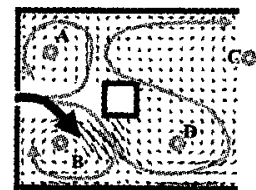

(d) $t=4 T / 8$

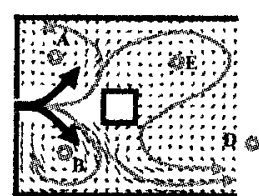

(f) $t=6 T / 8$

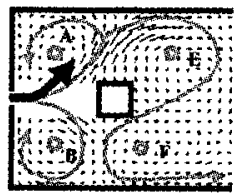

(h) $t=8 T / 8$
Fig. 3 Flow pattern in one cycle, at $B / b=15$, $d b=2.5 d / b=7$ and $R e=500$ 


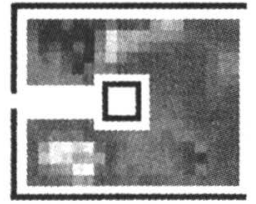

(a) $t=78$

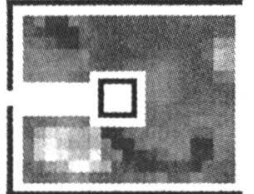

(c) $t=3778$

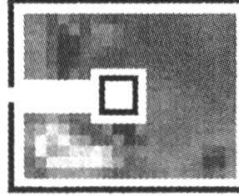

(e) $t=5778$

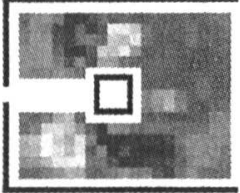

(g) $t=7 \pi 8$

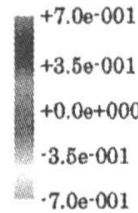

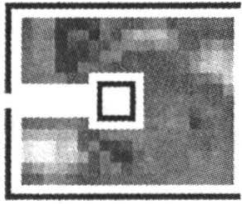

(b) $t=278$

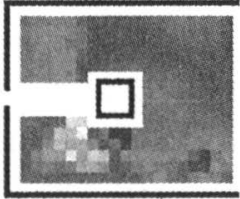

(d) $t=4778$

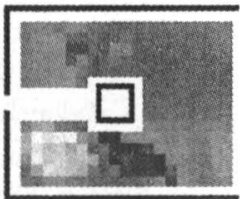

(f) $t=6778$

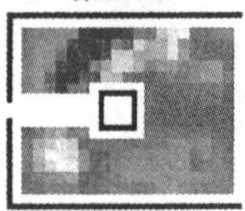

(h) $t=878$
Fig. 4 Vorticity distribution in one cycle, at $B / b=15$, $d b=2.5 d / b=7$ and $R e=500$.

\subsection{2 フローパターンの分類}

多くの PIV 解析の結果、著者らはフローパターンを 30 のタイプに分類した。 これらのフローパターンのタイプ をFig. 5 に示す。 また，各フローパターンが現れる発振 器形状の領域を Fig. 6 に示寸. typeA では噴流は発振し ている. Fig. 3 ように, 正方形柱下流で, 交互に 2 つの 渦構造が生成され，下流に流される。

$B l b$ を増加，あるいは, $d b$ を増加， $d / b$ を減少させる と,フローパターンは typeA からの typeB に移る. typeB に関しては，流れは上下対称であり，発振はしない。対 称な 2 組の渦構造が正方形柱の上流と下流に存在し, そ れらは下流に流されない. typeA と B の境界を次の方程 式により近似的に与える.

$$
d / b=0.18 B / b+1.50 d b+0.60
$$

(発振範囲, $0.5 \leqq d b \leqq 4,10 \leqq B / b \leqq 60$ )

$B / b$ を減少あるいは, $d / b$ を増加させると, フローパタ ーンは typeA からの typeC に移る．ただし， $d b$ の変化 でフローパターンはあまり影響を受けない. typeC に関 しては，噴流発振はせず噴流は片側に偏向し，正方形柱 にはほとんど衝突しない. typeA と typeC の間の境界は, 次の近似式によって表わすことができる．また，1つの

支配的な渦構造だけが正方形柱の上流と下流に各一個の み存在する。

$$
\begin{aligned}
& d / b=0.33 B / b+4.10 \\
& d / b=23
\end{aligned}
$$

(発振範囲, $0.5 \leqq d b \leqq 4,10 \leqq B / b \leqq 60$ )

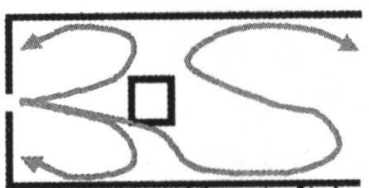

(a) type A(periodic)

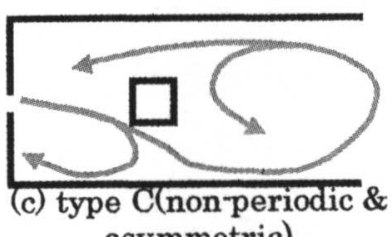

asymmetric)

Fig. 53 types of flow pattern.

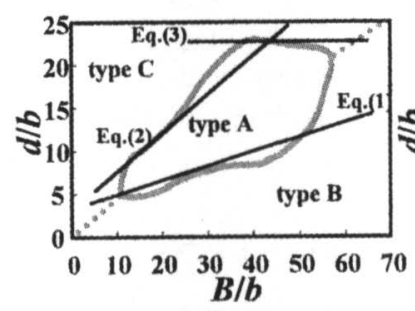

(a) $d b=2.5$

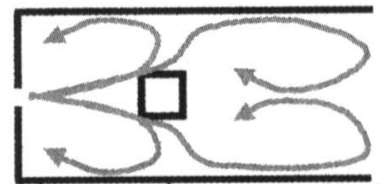

(b) type B(non-periodic \& symmetric) (b) $B I b=15$

Fig. 6 Regime of flow patterns at $R e=500$.

\section{2 発振器内部流れと発振周波数}

4.1.1 より発振器内では 4 つの渦 A, B, C, D が存在 し, 後方の渦 $\mathrm{C}$ と渦 $\mathrm{D}$ によって正方形柱後方に $\mathrm{S}$ 字型の 流れを形成することが確認できた。これらの渦, 流れが 噴流発振に関倸すると考えられるため, 発振器内に制御 物体を設置し，流れ場への影響や $S t$ 一の影響を調べた。

\subsection{1 制御平板設置による流れ場への影響}

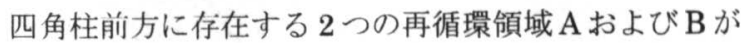
発振周波数に与える影響を調べるため, Fig. 7 の(a)のよ うに制御平板 Plate A を設置し，AおよびBの大きさを 変化させ, $S t$ 一の影響を調べた。結果をFig. 8 の(a)に示 す. Fig.より $d / b=7,9$ のどちらにおいても Stにはあま り影響しないことが分かる。 また， $L_{\mathrm{a}}=10$ 以上では $\mathrm{A}$ お よび B は存在せず，噴流は発振しない，以上の結果から 角柱前方の二つの渦は発振には必要不可欠だが，その大 きさは $S t$ に影響しないことが分かる。

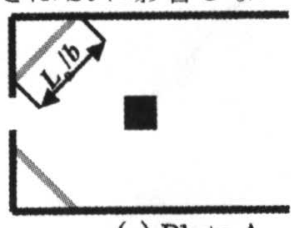

(a) Plate A

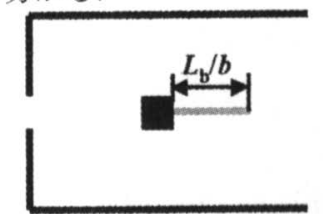

(b) Plate B
Fig. 7 The position of a control plate. 
次に, 四角柱後方に存在する渦構造 C および D が発振 周波数に与える影響を調べるため, Fig. 7 の(b)のように 制御平板 Plate B を設置し， Stへの影響を調べた。結果 をFig. 8 の(b)に示す. Fig. より平板を長くしていくと $d / b=7,9$ ともに $S t$ は直線的に減少していき， $L_{\mathrm{o}} / b=12.5$ 以降では噴流は発振しなくなることがわかる.

以上の結果より，四角柱後方の流れが噴流の発振周波 数に関係しており，また，噴流が発振するためには、噴 流が四角柱後方で偏向している側から偏向してない側 流れ込む必要があることがわかる。

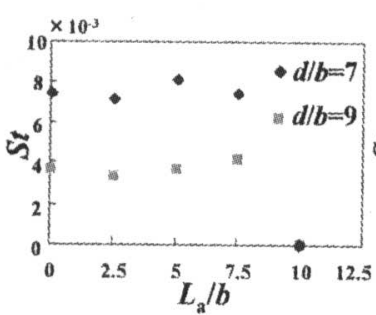

(a) Plate A

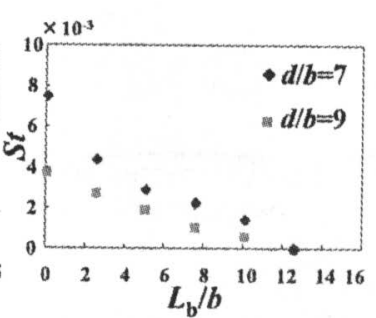

(b) Plate B
Fig. 8 Strouhal number $S t$ against Control plate length $L_{\mathrm{a}}$ and $L_{\mathrm{b}}$, at $d d=2.5, B / d=15$ and $R e=500$.

\subsection{2 発振周波数の決定}

4.2.1 より, 噴流の発振周波数は正方形柱後方の $\mathrm{S}$ 字流 れが関係していることが確認された。そこで，S 字流れ の長さ $L_{s}$ と $S t$ との関係を, $L_{\mathrm{b}} / b$ および $d / b$ を変化させ, 調査した。なお，LsはFig. 9 に示すように定義する. 結果をFig. 10 に示す. Fig. より $L_{b} / b$ および $d / b$ を変化 させた時共に, プロットはほぼ同じ 1 つの直線上

$$
S t=-0.309 L_{S} / b+17.3
$$

に並ぶ.このことから $L_{s} / b$ の長さが発振周波数に影響寸 ることが確認できる.
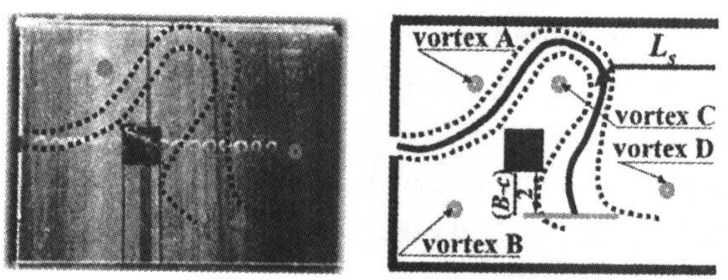

Fig. 9 The definition of length $L_{\delta} / b$.

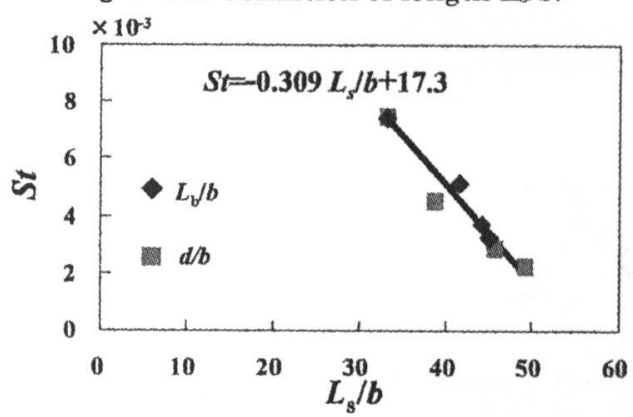

Fig. 10 Strouhal number St against length of a flow $L_{s} / b$, at $B / b=15, d B=2.5$ and $R e=500$.

\section{5. 結言}

今回の拘束噴流に関する実験により, 著者らは, 噴流発 振 1 周期分のフルイディック発振器内の連続したフロー パターンを明らかにした. また, 発振, 非発振でフロー パターンを 3 つのタイプに分類し, 境界となる経験式を 提案した. さらに, 噴流発振には正方形柱後方の $\mathrm{S}$ 字流 れが大きく関係していることを示し無次元発振周波数 $S t$ と $\mathrm{S}$ 字流れの長さ $L_{\mathrm{s}}$ との関係式を示した.

\section{参考文献}

1) H, Yamasaki., A, Takahashi., S, Honda. : A new fluidic oscillator for flow measurement, Proceedings of FLUCOM(Sheffield), (1988) pp. 16-20.

2) 尾崎省太郎, 原美明, : 純流体素子入門, 日刊工業新聞社 (1967).

3) J, R, Tippetts. H, K, Ng. J, K, Royle. : A fluidic flowmeter, Automatica (1973) pp. 35-45.

4) T, Shakouchi. : A new fluidic oscillator, flowmeter, without control port and feedback loop, Transactions of ASME Journal of Dynamic Systems, Measurement and Control, Vol. 111 (1989) pp. 535-539.

5) N, Matoba. K, Hirata. J, Funaki. : A Study on a fluidic oscillator at low Reynolds numbers, International Symposium on Micro-Mechanical Engineering, (2003) pp.357-362. 